\title{
Estimation of the Enrichment of Cs in Molten Chloride and Fluoride Systems by Molecular Dynamics Simulation
}

\author{
Masahiko Matsumiya and Ryuzo Takagia \\ Matsumiya Computational Chemistry Institute, \\ 6-14 higashi-numa, machiya-aza, chiaki-cho, ichinomiya-shi, Aichi 491-0813 Japan \\ ${ }^{a}$ Research Laboratory for Nuclear Reactors, Tokyo Institute of Technology, \\ O-okayama, Meguro-ku, Tokyo 152-8550 Japan \\ Reprint requests to Prof. M. M.; Fax: 81 586-76-6473; E-mail: molten@d9.dion.ne.jp
}

Z. Naturforsch. 56 a, 279-287 (2001); received December 8, 2000

For the pyrochemical reprocessing of spent metallic fuels in molten salt baths it is of importance to estimate the enrichment degree of Cs. A molecular dynamics simulation has been executed on molten $(\mathrm{Li}, \mathrm{Na}, \mathrm{Cs}) \mathrm{Cl}$ at $900 \mathrm{~K}$ and $(\mathrm{Li}, \mathrm{Na}, \mathrm{Cs}) \mathrm{F}$ at $925 \mathrm{~K}$ for various compositions in order to calculate the relative differences in the internal cation mobilities of $\mathrm{Cs}$ in molten $\mathrm{LiCl}$ $\mathrm{NaCl}$ equimolar mixtures and the LiF-NaF eutectic. According to these results the self-exchange velocities of $\mathrm{Li}^{+}, \mathrm{Na}^{+}$and $\mathrm{Cs}^{+}$with respect to $\mathrm{Cl}^{-}$and $\mathrm{F}^{-}$have similar tendencies at each composition, and $\mathrm{Cs}$ can be enriched effectively up to $x_{\mathrm{Cs}}=0.5-0.6$ in $\mathrm{LiCl}-\mathrm{NaCl}$ melts. In addition, the sequence of the calculated self-diffusion coefficients for various compositions was in a fair agreement with that of the obtained self-exchange velocities.

Key words: Molten Ternary Fluorides; Molecular Dynamics Simulation; Internal Cation Mobility; Self-exchange Velocity; Self-diffusion Coefficient.

\section{Introduction}

One should become able to separate fission products (FPs) like Cs and Sr from one another for incineration, utilization as medical tracers, precious materials, and so on. For this purpose we have already studied continuous countercurrent electromigration [1] and electrowinning methods [2 - 6], following the Argonne National Laboratory's proposal [7], in order to recover all alkali, alkaline-earth and more electrochemically basic rare earth residues, which remain in the fused salt bath after the electrorefining and drawdown processes. Thus, FPs like alkali and alkalineearth elements in the salt phase should be removed in order to employ the salt bath repeatedly. However, it is difficult to withdraw these elements from the salt bath because of their more negative decomposition potentials [8] than those of the solvent components. We have, e.g., previously performed an electrochemical investigation of the alloy formation mechanism of the electrochemically negative elements $\mathrm{Eu}^{2+}[2,3], \mathrm{Sr}^{2+}$ $[2,3], \mathrm{Ba}^{2+}[4,5]$, and $\mathrm{Cs}^{+}[6]$, in molten chloride and fluoride systems by means of transitory techniques, i. e., voltammetry, chronopotentiometry and electro- chemical impedance spectroscopy. Among these elements, it is more difficult to recover Cs than any other element, and our attempts to recover $\mathrm{Cs}$ in chloride baths by using a liquid $\mathrm{Pb}$ cathode as electrowinning method were unsuccessful [6]. On the other hand, countercurrent electromigration [1] has shown a significant possibility to recover Cs in a chloride bath, and a more detailed study to clarify the limitation of this process was necessary because the enrichment of Cs would be limited by the Chemla effect [9]. After previous results on $(\mathrm{Li}, \mathrm{K}, \mathrm{Cs}) \mathrm{Cl}[10]$ and $(\mathrm{Na}$, $\mathrm{K}, \mathrm{Cs}) \mathrm{Cl}$ [11], ( $\mathrm{Li}, \mathrm{Na}, \mathrm{Cs}) \mathrm{Cl}$ was selected. In addition we aimed at enriching $\mathrm{Cs}$ in molten fluoride systems because we successfully recovered Cs on a liquid $\mathrm{Pb}$ cathode in FLINAK melts [6]. Therefore we performed an MD simulation on molten $(\mathrm{Li}$, $\mathrm{Na}, \mathrm{Cs}) \mathrm{F}$. The unitary and binary systems $\mathrm{CsCl},(\mathrm{Li}$, $\mathrm{Na}) \mathrm{Cl}, \mathrm{CsF}$ and $(\mathrm{Li}, \mathrm{Na}) \mathrm{F}$ were also simulated for comparison with the ternary systems. Few studies on molten ternary fluoride systems containing Cs seem to exist in the literature. It also seems worthwhile to examine the order of the internal mobilities with increasing contents of $\mathrm{Cs}$ in molten alkali fluorides. Recently we have demonstrated the enrichment of 
Table 1-1. The parameters used in the calculation for pure salt and binary chloride and fluoride systems.

\begin{tabular}{ccccc}
\hline $\begin{array}{c}\text { System } \\
(\mathrm{Li}: \mathrm{K}: \mathrm{Cs})\end{array}$ & Ion Pair & $\rho / \mathrm{nm}$ & $c_{i j} / 10^{-79} \mathrm{~J} \cdot \mathrm{m}^{6}$ & $d_{i j} / 10^{-99} \mathrm{~J} \cdot \mathrm{m}^{8}$ \\
\hline$(0: 0: 100)$ & & & & \\
& $\mathrm{Cs}-\mathrm{Cs}$ & 0.334 & 152.0 & 278.0 \\
& $\mathrm{Cs}-\mathrm{Cl}$ & & 129.0 & 250.0 \\
& $\mathrm{Cl}-\mathrm{Cl}$ & & 129.0 & 260.0 \\
$(50: 50: 0))$ & $\mathrm{Li}-\mathrm{Li}$ & 0.330 & 0.073 & 0.030 \\
& $\mathrm{Li}-\mathrm{Na}$ & & 0.341 & 0.151 \\
& $\mathrm{Li}-\mathrm{Cl}$ & & 1.946 & 2.354 \\
& $\mathrm{Na}-\mathrm{Na}$ & & 1.680 & 0.800 \\
& $\mathrm{Na}-\mathrm{Cl}$ & & 10.944 & 13.597 \\
& $\mathrm{Cl}-\mathrm{Cl}$ & & 113.677 & 228.355 \\
$(0: 0: 100)$ & $\mathrm{Cs}-\mathrm{Cs}$ & 0.282 & 152.0 & 278.0 \\
& $\mathrm{Cs}-\mathrm{F}$ & & 52.0 & 78.0 \\
& $\mathrm{~F}-\mathrm{F}$ & & 19.1 & 23.0 \\
$(60: 40: 0)$ & $\mathrm{Li}-\mathrm{Li}$ & 0.311 & 0.073 & 0.030 \\
& $\mathrm{Li}-\mathrm{Na}$ & & 0.341 & 0.151 \\
& $\mathrm{Li}-\mathrm{F}$ & & 0.809 & 0.647 \\
& $\mathrm{Na}-\mathrm{Na}$ & & 1.680 & 0.800 \\
& $\mathrm{Na}-\mathrm{F}$ & & 4.435 & 3.691 \\
& $\mathrm{~F}-\mathrm{F}$ & & 15.299 & 18.179 \\
\hline
\end{tabular}

$b=0.338 \cdot 10^{-19} \mathrm{~J}, \sigma\left(\mathrm{Li}^{+}\right)=81.6 \mathrm{pm}, \sigma\left(\mathrm{Na}^{+}\right)=117.0 \mathrm{pm}, \sigma\left(\mathrm{Cs}^{+}\right)=$ $172.0 \mathrm{pm}, \sigma\left(\mathrm{Cl}^{-}\right)=158.5 \mathrm{pm}, \sigma\left(\mathrm{F}^{-}\right)=117.9 \mathrm{pm}$.

$\mathrm{CsCl}$ in molten $\mathrm{LiCl}-\mathrm{KCl}$ eutectic [10] and in molten $\mathrm{NaCl}-\mathrm{KCl}$ equimolar mixtures [11] by MD simulation. Here we wanted to see if the enrichment of Cs in molten fluorides can be deduced from the self-exchange velocity (SEV) and self-diffusion coefficients obtained by MD simulation.

\section{The Molecular Dynamics Simulation}

In each MD simulation run we used 1000 ion pairs placed in a basic cube with periodic boundary conditions, the side length $L$ of which was determined from the molar volumes of the pure melts on the assumption of additivity. Pair potentials of the BornMayer-Huggins type were applied:

$$
\begin{aligned}
\Phi_{i j}= & \frac{z_{i} z_{j} e^{2}}{4 \pi \varepsilon_{0} r}+A_{i j} b \exp \left[\left(\sigma_{i}+\sigma_{j}-r\right) / \rho\right] \\
& -\frac{c_{i j}}{r^{6}}-\frac{d_{i j}}{r^{8}}, \\
A_{i j}= & 1+\frac{z_{i}}{n_{i}}+\frac{z_{j}}{n_{j}},
\end{aligned}
$$

where $z_{i}$ and $z_{j}$ are the formal charges of the ions $i$ and $j, r$ the distance between the two particles, $b$

\begin{tabular}{|c|c|c|c|c|}
\hline $\begin{array}{c}\text { System } \\
(\mathrm{Li}: \mathrm{K}: \mathrm{Cs})\end{array}$ & Ion Pair & $\rho / \mathrm{nm}$ & $c_{i j} / 10^{-79} \mathrm{~J} \cdot \mathrm{m}^{6}$ & $d_{i j} / 10^{-99} \mathrm{~J} \cdot \mathrm{m}^{8}$ \\
\hline$(45: 45: 10)$ & $\begin{array}{c}\mathrm{Li}-\mathrm{Li} \\
\mathrm{Li}-\mathrm{Na} \\
\mathrm{Li}-\mathrm{Cs} \\
\mathrm{Li}-\mathrm{Cl} \\
\mathrm{Na}-\mathrm{Na} \\
\mathrm{Na}-\mathrm{Cs} \\
\mathrm{Na}-\mathrm{Cl} \\
\mathrm{Cs}-\mathrm{Cs} \\
\mathrm{Cs}-\mathrm{Cl} \\
\mathrm{Cl}-\mathrm{Cl}\end{array}$ & 0.3300 & $\begin{array}{r}0.073 \\
0.341 \\
2.837 \\
1.960 \\
1.680 \\
15.062 \\
11.020 \\
152.0 \\
124.087 \\
115.158\end{array}$ & $\begin{array}{c}0.030 \\
0.151 \\
3.177 \\
2.371 \\
0.800 \\
17.361 \\
13.695 \\
278.0 \\
238.138 \\
231.405\end{array}$ \\
\hline$(40: 40: 20)$ & $\begin{array}{l}\mathrm{Li}-\mathrm{Cl} \\
\mathrm{Na}-\mathrm{Cl} \\
\mathrm{Cs}-\mathrm{Cl} \\
\mathrm{Cl}-\mathrm{Cl}\end{array}$ & 0.3304 & $\begin{array}{r}1.973 \\
11.096 \\
124.920 \\
116.650\end{array}$ & $\begin{array}{r}2.389 \\
13.793 \\
239.779 \\
234.480\end{array}$ \\
\hline$(35: 35: 30)$ & $\begin{array}{l}\mathrm{Li}-\mathrm{Cl} \\
\mathrm{Na}-\mathrm{Cl} \\
\mathrm{Cs}-\mathrm{Cl} \\
\mathrm{Cl}-\mathrm{Cl}\end{array}$ & 0.3309 & $\begin{array}{r}1.987 \\
11.172 \\
125.754 \\
118.153\end{array}$ & $\begin{array}{r}2.406 \\
13.892 \\
241.422 \\
237.581\end{array}$ \\
\hline$(30: 30: 40)$ & $\begin{array}{l}\mathrm{Li}-\mathrm{Cl} \\
\mathrm{Na}-\mathrm{Cl} \\
\mathrm{Cs}-\mathrm{Cl} \\
\mathrm{Cl}-\mathrm{Cl}\end{array}$ & 0.3313 & $\begin{array}{r}2.001 \\
11.249 \\
126.590 \\
119.668\end{array}$ & $\begin{array}{r}2.423 \\
13.991 \\
243.068 \\
240.706\end{array}$ \\
\hline$(25: 25: 50)$ & $\begin{array}{l}\mathrm{Li}-\mathrm{Cl} \\
\mathrm{Na}-\mathrm{Cl} \\
\mathrm{Cs}-\mathrm{Cl} \\
\mathrm{Cl}-\mathrm{Cl}\end{array}$ & 0.3318 & $\begin{array}{r}2.015 \\
11.325 \\
127.427 \\
121.195\end{array}$ & $\begin{array}{r}2.441 \\
14.090 \\
244.718 \\
243.856\end{array}$ \\
\hline$(20: 20: 60)$ & $\begin{array}{l}\mathrm{Li}-\mathrm{Cl} \\
\mathrm{Na}-\mathrm{Cl} \\
\mathrm{Cs}-\mathrm{Cl} \\
\mathrm{Cl}-\mathrm{Cl}\end{array}$ & 0.3322 & $\begin{array}{r}2.028 \\
11.402 \\
128.266 \\
122.733\end{array}$ & $\begin{array}{r}2.458 \\
14.189 \\
246.370 \\
247.032\end{array}$ \\
\hline$(15: 15: 70)$ & $\begin{array}{l}\mathrm{Li}-\mathrm{Cl} \\
\mathrm{Na}-\mathrm{Cl} \\
\mathrm{Cs}-\mathrm{Cl} \\
\mathrm{Cl}-\mathrm{Cl}\end{array}$ & 0.3327 & $\begin{array}{r}2.042 \\
11.479 \\
129.105 \\
124.282\end{array}$ & $\begin{array}{r}2.476 \\
14.288 \\
248.026 \\
250.233\end{array}$ \\
\hline$(10: 10: 80)$ & $\begin{array}{l}\mathrm{Li}-\mathrm{Cl} \\
\mathrm{Na}-\mathrm{Cl} \\
\mathrm{Cs}-\mathrm{Cl} \\
\mathrm{Cl}-\mathrm{Cl}\end{array}$ & 0.3331 & $\begin{array}{r}2.056 \\
11.556 \\
129.946 \\
125.844\end{array}$ & $\begin{array}{r}2.493 \\
14.388 \\
249.684 \\
253.459\end{array}$ \\
\hline$(5: 5: 90)$ & $\begin{array}{l}\mathrm{Li}-\mathrm{Cl} \\
\mathrm{Na}-\mathrm{Cl} \\
\mathrm{Cs}-\mathrm{Cl} \\
\mathrm{Cl}-\mathrm{Cl}\end{array}$ & 0.3336 & $\begin{array}{r}2.070 \\
11.633 \\
130.789 \\
127.417\end{array}$ & $\begin{array}{r}2.511 \\
14.488 \\
251.346 \\
256.711\end{array}$ \\
\hline
\end{tabular}

Table 1-2. The parameters used in the calculation for molten alkali ternary chloride and fluoride systems.

and $\rho$ denote repulsion energy parameters, $c_{i j}$ and $d_{i j}$ dispersion energy parameters, $e$ the elementary charge, $\sigma_{i}$ and $\sigma_{j}$ the ionic radii of the ions $i$ and $j, \varepsilon_{0}$ the permittivity of vacuum and $A$ the Pauling factor. The first term in (1) represents the Coulomb interaction, the second the Born-Huggins exponential repulsion with parameters provided by Tosi and Fumi [12] while the third and fourth terms represent 
Table 1-2 (continued).

\begin{tabular}{|c|c|c|c|c|}
\hline $\begin{array}{c}\text { System } \\
\text { (Li:K:Cs) }\end{array}$ & Ion Pair & $\rho / \mathrm{nm}$ & $c_{i j} / 10^{-79} \mathrm{~J} \cdot \mathrm{m}^{6}$ & $d_{i j} / 10^{-99} \mathrm{~J} \cdot \mathrm{m}^{8}$ \\
\hline$(54: 36: 10)$ & $\begin{array}{c}\mathrm{Li}-\mathrm{Li} \\
\mathrm{Li}-\mathrm{Na} \\
\mathrm{Li}-\mathrm{Cs} \\
\mathrm{Li}-\mathrm{F} \\
\mathrm{Na}-\mathrm{Na} \\
\mathrm{Na}-\mathrm{Cs} \\
\mathrm{Na}-\mathrm{F} \\
\mathrm{Cs}-\mathrm{Cs} \\
\mathrm{Cs}-\mathrm{F} \\
\mathrm{F}-\mathrm{F}\end{array}$ & 0.3085 & $\begin{array}{r}0.073 \\
0.341 \\
2.837 \\
0.816 \\
1.680 \\
15.062 \\
4.478 \\
152.0 \\
48.029 \\
15.734\end{array}$ & $\begin{array}{c}0.030 \\
0.151 \\
3.177 \\
0.653 \\
0.800 \\
17.361 \\
3.730 \\
278.0 \\
72.491 \\
18.721\end{array}$ \\
\hline$(48: 32: 20)$ & $\begin{array}{l}\mathrm{Li}-\mathrm{F} \\
\mathrm{Na}-\mathrm{F} \\
\mathrm{Cs}-\mathrm{F} \\
\text { F-F }\end{array}$ & 0.3055 & $\begin{array}{r}0.822 \\
4.517 \\
48.588 \\
16.160\end{array}$ & $\begin{array}{r}0.658 \\
3.766 \\
73.373 \\
19.254\end{array}$ \\
\hline$(42: 28: 30)$ & $\begin{array}{c}\text { Li-F } \\
\text { Na-F } \\
\text { Cs-F } \\
\text { F-F }\end{array}$ & 0.3026 & $\begin{array}{r}0.827 \\
4.553 \\
49.114 \\
16.575\end{array}$ & $\begin{array}{r}0.663 \\
3.800 \\
74.207 \\
19.774\end{array}$ \\
\hline$(36: 24: 40)$ & $\begin{array}{c}\text { Li-F } \\
\text { Na-F } \\
\text { Cs-F } \\
\text { F-F }\end{array}$ & 0.2996 & $\begin{array}{r}0.832 \\
4.586 \\
49.607 \\
16.978\end{array}$ & $\begin{array}{r}0.668 \\
3.831 \\
74.992 \\
20.282\end{array}$ \\
\hline$(30: 20: 50)$ & $\begin{array}{l}\text { Li-F } \\
\text { Na-F } \\
\text { Cs-F } \\
\text { F-F }\end{array}$ & 0.2967 & $\begin{array}{r}0.836 \\
4.615 \\
50.066 \\
17.369\end{array}$ & $\begin{array}{r}0.672 \\
3.859 \\
75.726 \\
20.777\end{array}$ \\
\hline$(24: 16: 60)$ & $\begin{array}{c}\text { Li-F } \\
\text { Na-F } \\
\text { Cs-F } \\
\text { F-F }\end{array}$ & 0.2938 & $\begin{array}{r}0.839 \\
4.640 \\
50.491 \\
17.745\end{array}$ & $\begin{array}{r}0.675 \\
3.884 \\
76.408 \\
21.256\end{array}$ \\
\hline$(18: 12: 70)$ & $\begin{array}{c}\text { Li-F } \\
\text { Na-F } \\
\text { Cs-F } \\
\text { F-F }\end{array}$ & 0.2908 & $\begin{array}{r}0.842 \\
4.662 \\
50.879 \\
18.108\end{array}$ & $\begin{array}{r}0.678 \\
3.906 \\
77.037 \\
21.719\end{array}$ \\
\hline$(12: 8: 80)$ & $\begin{array}{l}\mathrm{Li}-\mathrm{F} \\
\mathrm{Na}-\mathrm{F} \\
\text { Cs-F } \\
\text { F-F }\end{array}$ & 0.2879 & $\begin{array}{r}0.844 \\
4.680 \\
51.232 \\
18.455\end{array}$ & $\begin{array}{r}0.680 \\
3.925 \\
77.612 \\
22.165\end{array}$ \\
\hline$(6: 4: 90)$ & $\begin{array}{c}\text { Li-F } \\
\text { Na-F } \\
\text { Cs-F } \\
\text { F-F }\end{array}$ & 0.2849 & $\begin{array}{r}0.845 \\
4.695 \\
51.547 \\
18.786\end{array}$ & $\begin{array}{r}0.682 \\
3.941 \\
78.130 \\
22.592\end{array}$ \\
\hline
\end{tabular}

the dipole-dipole and dipole-quadrupole dispersion energies with parameters given by Mayer [13]. The corresponding parameters for the mixture were determined by the combination rule given by Larsen et al. [14]. More detailed data of the adopted values of $A, b, \rho, r, c$ and $d$ for chloride and fluoride are listed in Tables 1-1 and 1-2, respectively. The Ewald method [15] was employed for the calculation of the Coulomb forces; the cutoff distance in real space was $L / 2$, and
Table 2-1. Characteristic values of the $g_{i j}(r)$ 's of cation-anion and anion-anion pairs in the molten ternary system $(\mathrm{Li}$, $\mathrm{Na}, \mathrm{Cs}) \mathrm{Cl}$ at $900 \mathrm{~K} . R_{1}$ and $R_{2}$ are the distances where $g_{i j}(r)$ crosses unity for the first and second time, respectively. $R_{\mathrm{M}}$ and $R_{\mathrm{m}}$ are the distances at the first maximum and minimum, respectively. $n_{\text {eq }}\left(R_{2}-R_{\mathrm{m}}\right)$ is the partial equivalent coordination number within $R_{2}-R_{\mathrm{m}}$ of a cation, which is equal to the coordination number of anions around the cation.

\begin{tabular}{cccccccc}
\hline $\begin{array}{c}\text { System } \\
\text { (Li:K:Cs) }\end{array}$ & $\begin{array}{c}\text { Ion } \\
\text { Pair }\end{array}$ & $\begin{array}{c}R_{1} / \\
\mathrm{nm}\end{array}$ & $\begin{array}{c}R_{\mathrm{M}} / \\
\mathrm{nm}\end{array}$ & $g\left(R_{\mathrm{M}}\right)$ & $\begin{array}{c}R_{2} / \\
\mathrm{nm}\end{array}$ & $\begin{array}{c}R_{\mathrm{m}} / \\
\mathrm{nm}\end{array}$ & $\begin{array}{c}n_{\mathrm{eq}} \\
\left(R_{2}-R_{\mathrm{m}}\right)\end{array}$ \\
\hline (50:50:0) & $\mathrm{Li}-\mathrm{Cl}$ & 0.196 & 0.225 & 4.54 & 0.283 & 0.350 & $3.24-4.14$ \\
& $\mathrm{Na}-\mathrm{Cl}$ & 0.231 & 0.261 & 3.37 & 0.324 & 0.403 & $3.82-5.35$ \\
$(40: 40: 20)$ & $\mathrm{Li}-\mathrm{Cl}$ & 0.194 & 0.224 & 5.88 & 0.285 & 0.361 & $3.20-3.86$ \\
& $\mathrm{Na}-\mathrm{Cl}$ & 0.228 & 0.261 & 4.19 & 0.325 & 0.405 & $3.57-4.78$ \\
& $\mathrm{Cs}-\mathrm{Cl}$ & 0.301 & 0.335 & 2.72 & 0.408 & 0.493 & $4.85-7.20$ \\
$(30: 30: 40)$ & $\mathrm{Li}-\mathrm{Cl}$ & 0.191 & 0.221 & 6.92 & 0.282 & 0.366 & $3.16-3.75$ \\
& $\mathrm{Na}-\mathrm{Cl}$ & 0.225 & 0.259 & 4.86 & 0.323 & 0.405 & $3.53-4.48$ \\
& $\mathrm{Cs}-\mathrm{Cl}$ & 0.298 & 0.331 & 3.07 & 0.408 & 0.492 & $4.63-6.58$ \\
$(20: 20: 60)$ & $\mathrm{Li}-\mathrm{Cl}$ & 0.190 & 0.220 & 7.81 & 0.283 & 0.366 & $3.16-3.71$ \\
& $\mathrm{Na}-\mathrm{Cl}$ & 0.225 & 0.256 & 5.58 & 0.323 & 0.412 & $3.49-4.34$ \\
& $\mathrm{Cs}-\mathrm{Cl}$ & 0.295 & 0.330 & 3.53 & 0.405 & 0.499 & $4.41-6.28$ \\
$(10: 10: 80)$ & $\mathrm{Li}-\mathrm{Cl}$ & 0.188 & 0.219 & 8.61 & 0.284 & 0.366 & $3.19-3.60$ \\
& $\mathrm{Na}-\mathrm{Cl}$ & 0.224 & 0.255 & 6.29 & 0.322 & 0.410 & $3.49-4.22$ \\
& $\mathrm{Cs}-\mathrm{Cl}$ & 0.292 & 0.326 & 3.87 & 0.402 & 0.501 & $4.41-5.95$ \\
& $\mathrm{Cs}-\mathrm{Cl}$ & 0.299 & 0.333 & 4.54 & 0.406 & 0.506 & $4.60-5.97$ \\
\hline
\end{tabular}

the reciprocal lattice vectors $\left|(\boldsymbol{n})^{2}\right|$ were counted up to 27 . The convergence parameter $\alpha$ was $5.6 / \mathrm{L}$ and the time step $5 \mathrm{fs}$. At the beginning, MD runs were conducted with the constant temperature method of Woodcock [16]. After attainment of constant temperature by running several thousand steps, these were converted to constant energy runs. From the runs during more than $10^{4}$ time steps, using Verlet's algorithm after attainment of equilibrium, the structure and the other properties were obtained.

\section{Results and Discussion}

The pair correlation functions and the running coordination numbers with increasing the content of Cs for the ternary chloride and fluoride systems are given in Figs. 1-1 and 1-2, respectively. Various characteristic properties of the pair correlation functions and running coordination numbers of molten chlorides and fluorides are summarized in Tables 2-1 and $2-2$, respectively. The positions of the first peaks of the pair correlation functions $g_{\mathrm{Li}-\mathrm{Cl}}, g_{\mathrm{Na}-\mathrm{Cl}}, g_{\mathrm{Cs}-\mathrm{Cl}}$, $g_{\mathrm{Li}-\mathrm{F}}, g_{\mathrm{Na}-\mathrm{F}}$ and $g_{\mathrm{Cs}-\mathrm{F}}$ are much the same in the binary mixtures and the pure salts when compairing the pair correlation functions of the unitary $\mathrm{CsCl}$ and $\mathrm{CsF}$, 


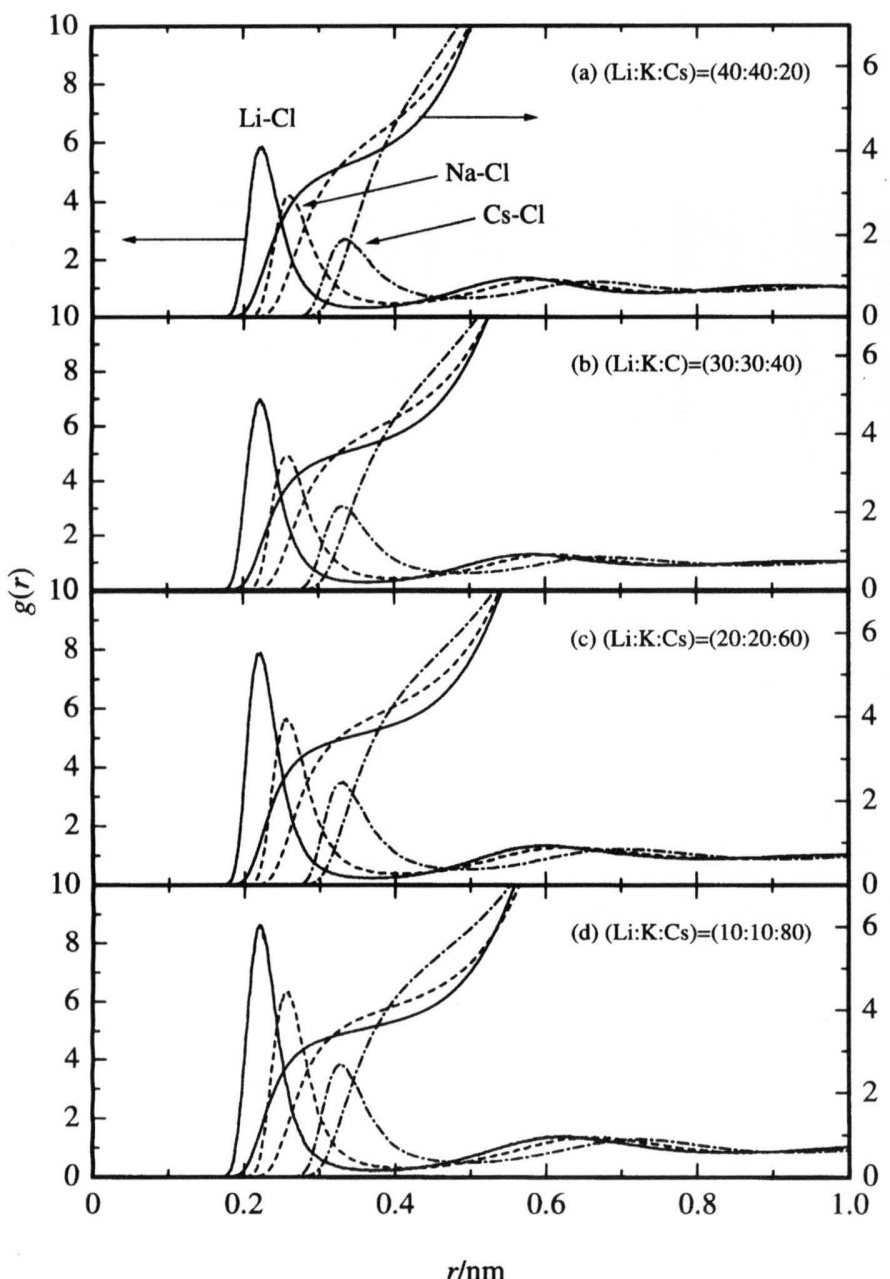

Fig. 1-1. The pair correlation functions, $g(r)$, and running coordination numbers, $n(r)$, of the molten ternary system $(\mathrm{Li}, \mathrm{Na}, \mathrm{Cs}) \mathrm{Cl}, g_{\mathrm{Li}-\mathrm{Cl}}$ solid line, $g_{\mathrm{Na}-\mathrm{Cl}}$ : broken line, $g_{\mathrm{Cs}-\mathrm{Cl}}$ : chain line.

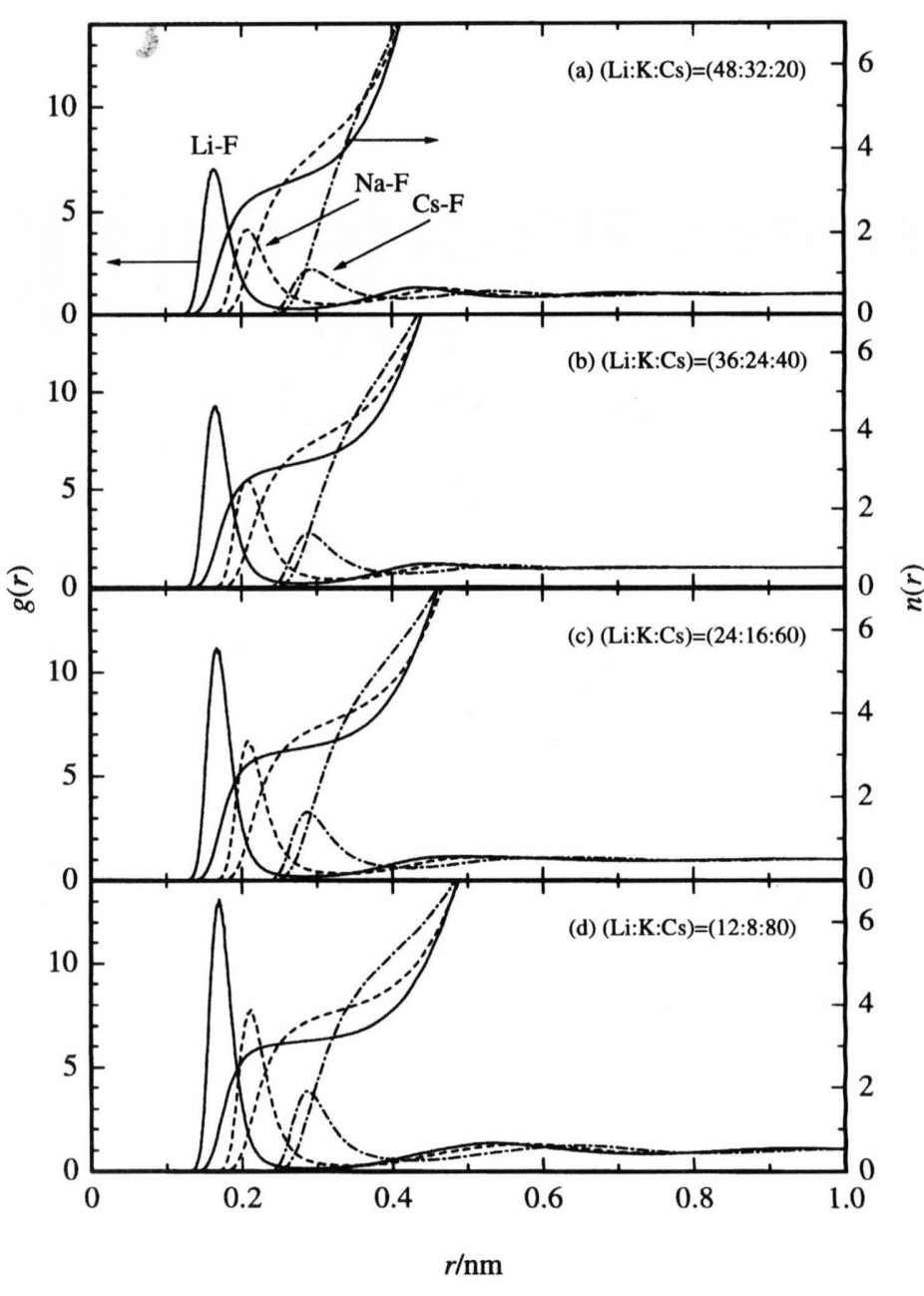

Fig. 1-2. The pair correlation functions, $g(r)$, and running coordination numbers, $n(r)$, of the molten ternary system $(\mathrm{Li}, \mathrm{Na}, \mathrm{Cs}) \mathrm{F}, g_{\mathrm{Li}-\mathrm{F}}$ : solid line, $g_{\mathrm{Na}-\mathrm{F}}$ : broken line, $g_{\mathrm{Cs}-\mathrm{F}}$ : chain line. 
Table 2-2. Characteristic values of the $g_{i j}(r)$ 's of cation-anion and anion-anion pairs in the molten ternary system $(\mathrm{Li}$, $\mathrm{Na}, \mathrm{Cs}) \mathrm{F}$ at $925 \mathrm{~K}$.

\begin{tabular}{|c|c|c|c|c|c|c|c|}
\hline $\begin{array}{c}\text { System } \\
(\mathrm{Li}: \mathrm{K}: \mathrm{Cs})\end{array}$ & $\begin{array}{l}\text { Ion } \\
\text { Pair }\end{array}$ & $\begin{array}{l}R_{1} / \\
\mathrm{nm}\end{array}$ & $\underset{\mathrm{nm}}{R_{\mathrm{M}}{ }^{\prime}}$ & $g\left(R_{\mathrm{M}}\right)$ & $\begin{array}{l}R_{2} l \\
\mathrm{~nm}\end{array}$ & $\begin{array}{c}R_{\mathrm{m}} / \\
\mathrm{nm}\end{array}$ & $\begin{array}{c}n_{\mathrm{eq}} \\
\left(R_{2}-R_{\mathrm{m}}\right)\end{array}$ \\
\hline \multirow[t]{2}{*}{$(60: 40: 0)$} & $\mathrm{Li}-\mathrm{F}$ & 0.137 & 0.163 & 50 & 0.213 & 0.270 & 2.82 \\
\hline & $\mathrm{Na}-\mathrm{F}$ & 33 & 0 & & 62 & 318 & \\
\hline \multirow[t]{3}{*}{$(48: 32: 20)$} & $\mathrm{Li}-\mathrm{F}$ & 0.137 & 0.164 & 7.02 & 0.213 & 0.276 & 2.8 \\
\hline & $\mathrm{Na}-\mathrm{F}$ & 0.183 & 0.209 & 4.14 & 0.262 & 0.323 & 4.32 \\
\hline & Cs-F & 0.265 & 0.293 & 20 & 61 & 0.416 & 7.34 \\
\hline \multirow[t]{3}{*}{$(36: 24: 40)$} & $\mathrm{Li}-\mathrm{F}$ & 38 & 0.165 & 9.33 & 0.213 & 0.282 & 2.86 \\
\hline & $\mathrm{Na}-\mathrm{F}$ & 0.181 & 0.209 & 5.42 & 0.262 & 0.337 & 4.20 \\
\hline & Cs-F & 0.260 & 0.290 & 2.80 & 0.357 & 0.423 & 6.68 \\
\hline \multirow[t]{3}{*}{$(24: 16: 60)$} & $\mathrm{Li}-\mathrm{F}$ & 0.140 & 0.166 & 11.09 & 0.215 & 0.283 & 3.21 \\
\hline & $\mathrm{Na}-\mathrm{F}$ & 0.181 & 0.208 & 6.56 & 0.262 & 0.342 & 4.03 \\
\hline & Cs-F & 0.256 & 0.286 & 3.28 & 0.352 & 0.423 & 4.40 \\
\hline \multirow[t]{3}{*}{$(12: 8: 80)$} & $\mathrm{Li}-\mathrm{F}$ & 0.142 & 0.167 & 12.98 & 0.215 & 0.292 & 2.9 \\
\hline & $\mathrm{Na}-\mathrm{F}$ & 0.183 & 0.210 & 7.76 & 0.263 & 0.344 & 3.95 \\
\hline & Cs-F & 0.256 & 0.286 & 3.86 & 0.351 & 0.424 & $4.32-5.66$ \\
\hline$(0: 0: 100)$ & Cs-F & 0.256 & 0.287 & 4.26 & 0.349 & 0.430 & $4.23-5.51$ \\
\hline
\end{tabular}

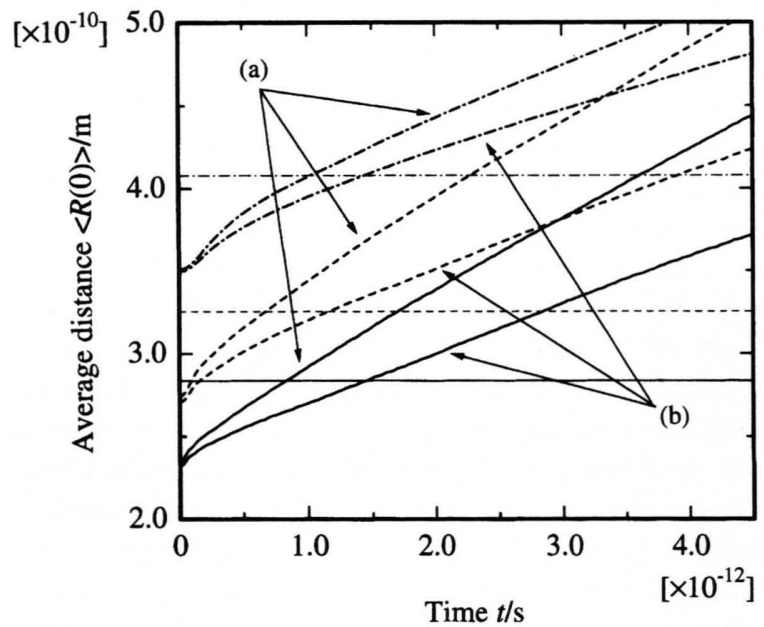

Fig. 2-1. Evolution of the average distance of marked $\mathrm{Li}^{+}$: solid line, $\mathrm{Na}^{+}$: broken line, $\mathrm{Cs}^{+}$: chain line from $\mathrm{Cl}^{-}$for the molten ternary system $(\mathrm{Li}, \mathrm{Na}, \mathrm{Cs}) \mathrm{Cl}$, (a) $x_{\mathrm{Cs}}=0.2$, (b) $x_{\mathrm{Cs}}=0.6$.

and of the binary $(\mathrm{Li}, \mathrm{Na}) \mathrm{Cl}$ and $(\mathrm{Li}, \mathrm{Na}) \mathrm{F}$ systems with the ternary mixtures for various compositions. With regard to the peak heights, $g_{\mathrm{Li}-\mathrm{Cl}}, g_{\mathrm{Na}-\mathrm{Cl}}, g_{\mathrm{Na}-\mathrm{F}}$ and $g_{\mathrm{Cs}-\mathrm{F}}$ are more sharply peaked in the ternary mixture than in the binary mixtures. $g_{\mathrm{Cs}-\mathrm{Cl}}$ and $g_{\mathrm{Cs}-\mathrm{F}}$ are less sharply peaked in the ternary mixtures than in the unitary $\mathrm{CsCl}$ and $\mathrm{CsF}$. The increasing rate of the peak heights for $\mathrm{Li}$ and $\mathrm{Na}$ is larger than for Cs. The

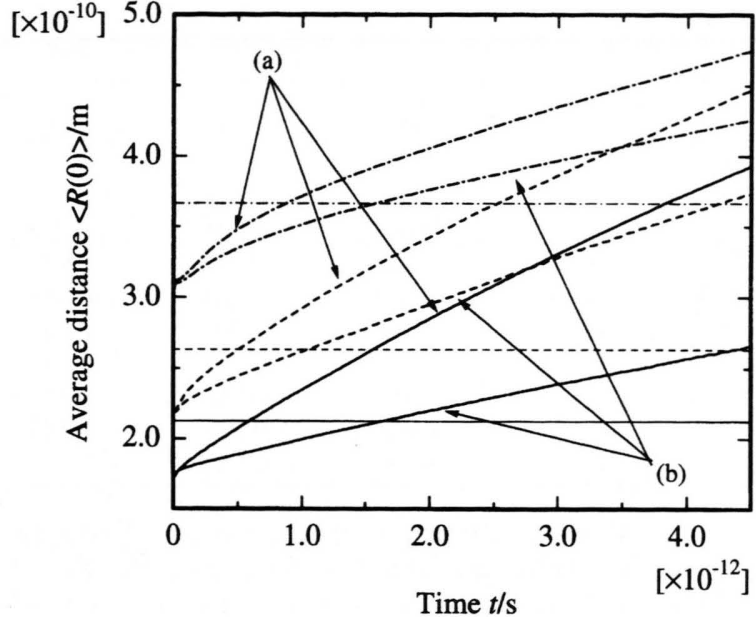

Fig. 2-2. Evolution of the average distance of marked $\mathrm{Li}^{+}$: solid line, $\mathrm{Na}^{+}$: broken line, $\mathrm{Cs}^{+}$: chain line from $\mathrm{F}^{-}$for the molten ternary system $(\mathrm{Li}, \mathrm{Na}, \mathrm{Cs}) \mathrm{F}$, (a) $x_{\mathrm{Cs}}=0.2$, (b) $x_{\mathrm{Cs}}=0.6$.

position of the second peak of $g_{+-}$is more distant for $\mathrm{LiCl}, \mathrm{NaCl}, \mathrm{LiF}$ and $\mathrm{NaF}$, and less distant for $\mathrm{CsCl}$ and $\mathrm{CsF}$ in the ternary mixture than in the respective binary and pure salts with increasing the amount of Cs. The running coordination numbers for each pair in the chloride and fluoride melts were rather similar.

The separating motion of cation-anion pairs could be expressed in terms of the self-exchange velocity (SEV), which was calculated by molecular dynamics simulation. The evolution of the average distance of marked cations from a $\mathrm{Cl}^{-}$and $\mathrm{F}^{-}$ions for each composition was shown in Figs. 2-1 and 2-2, respectively. The SEV, $v$, which was correlated with internal mobility [17], is defined by

$$
v=\frac{R_{2}-\langle R(0)\rangle}{\tau}
$$

where $R_{2}$ is the distance where the pair correlation function between cation and anion reaches unity after the first peak, and $\langle R(0)\rangle$ is the average distance of cations located within $R_{2}$ from a reference anion at $t=0 . t=\tau$ is the average time in which the average distance of such particles becomes $R_{2}$. Thus, the SEV is the velocity of the separating motion of neighboring unlike ion pairs and can be calculated with good precision from quite short MD simulation steps, since each anion has several neighboring cations. For the present system the SEV was calculated from 120 origins and from 150 origins using $10^{4}$ steps for binary 
Table 3-1. Relative differences (see (6)) calculated from the self-exchange velocities for molten chlorides at $900 \mathrm{~K}$.

\begin{tabular}{ccccc}
\hline$x_{\mathrm{Cs}}$ & $\varepsilon_{\mathrm{LiNa}}$ & $\varepsilon_{\mathrm{LiCs}}$ & $\varepsilon_{\mathrm{NaCs}}$ & $\varepsilon_{\mathrm{Cs}, \mathrm{sol} .}{ }^{*}$ \\
\hline 0 & -0.147 & & & \\
0.1 & -0.192 & 0.073 & 0.264 & -0.149 \\
0.2 & -0.266 & 0.015 & 0.281 & -0.122 \\
0.3 & -0.248 & -0.068 & 0.179 & -0.031 \\
0.4 & -0.316 & -0.081 & 0.234 & -0.045 \\
0.5 & -0.287 & -0.085 & 0.202 & -0.029 \\
0.6 & -0.293 & -0.158 & 0.135 & 0.041 \\
0.7 & -0.205 & -0.193 & 0.012 & 0.111 \\
0.8 & -0.179 & -0.201 & -0.023 & 0.130 \\
0.9 & -0.198 & -0.270 & -0.072 & 0.190 \\
\hline
\end{tabular}

Table 3-2. Relative differences (see (6)) calculated from the self-exchange velocities for molten fluorides at $925 \mathrm{~K}$.

\begin{tabular}{ccccc}
\hline$x_{\mathrm{Cs}}$ & $\varepsilon_{\mathrm{LiNa}}$ & $\varepsilon_{\mathrm{LiCs}}$ & $\varepsilon_{\mathrm{NaCs}}$ & $\varepsilon_{\mathrm{Cs}, \text { sol. }}{ }^{*}$ \\
\hline 0 & -0.152 & & & \\
0.1 & -0.186 & 0.110 & 0.296 & -0.185 \\
0.2 & -0.227 & 0.043 & 0.270 & -0.134 \\
0.3 & -0.453 & -0.139 & 0.315 & -0.043 \\
0.4 & -0.588 & -0.200 & 0.387 & -0.035 \\
0.5 & -0.583 & -0.270 & 0.313 & 0.037 \\
0.6 & -0.553 & -0.404 & 0.149 & 0.183 \\
0.7 & -0.444 & -0.460 & -0.016 & 0.282 \\
0.8 & -0.315 & -0.499 & -0.185 & 0.373 \\
0.9 & -0.231 & -0.558 & -0.328 & 0.466 \\
\hline
\end{tabular}

* The calculated values are based on the quasi-binary system [1].

and ternary mixtures, respectively. The solid, broken and chain lines exhibited in Fig. 2 were $R_{2}$ for $\mathrm{Li}, \mathrm{Na}$ and Cs, respectively. The orders of the $v$ 's were

$$
\begin{aligned}
& v_{\mathrm{Cs}}<v_{\mathrm{Li}}<v_{\mathrm{Na}}\left(x_{\mathrm{Cs}}=0.1-0.2\right), \\
& v_{\mathrm{Li}}<v_{\mathrm{Cs}}<v_{\mathrm{Na}}\left(x_{\mathrm{Cs}}=0.3-0.6\right), \\
& v_{\mathrm{Li}}<v_{\mathrm{Cs}} \approx v_{\mathrm{Na}}\left(x_{\mathrm{Cs}}=0.7\right), \\
& v_{\mathrm{Li}}<v_{\mathrm{Na}}<v_{\mathrm{Cs}}\left(x_{\mathrm{Cs}}=0.8-0.9\right) .
\end{aligned}
$$

On the other hand, the orders of the $v$ 's for fluoride system were

$$
\begin{aligned}
& v_{\mathrm{Cs}}<v_{\mathrm{Li}}<v_{\mathrm{Na}}\left(x_{\mathrm{Cs}}=0.1\right), \\
& v_{\mathrm{Cs}} \approx v_{\mathrm{Li}}<v_{\mathrm{Na}}\left(x_{\mathrm{Cs}}=0.2\right), \\
& v_{\mathrm{Li}}<v_{\mathrm{Cs}}<v_{\mathrm{Na}}\left(x_{\mathrm{Cs}}=0.3-0.6\right), \\
& v_{\mathrm{Li}}<v_{\mathrm{Na}}<v_{\mathrm{Cs}}\left(x_{\mathrm{Cs}}=0.7-0.9\right) .
\end{aligned}
$$

The relative differences in the SEV's were calculated from the equation

$$
\varepsilon_{\alpha \beta}=\frac{v_{\alpha}-v_{\beta}}{x_{\mathrm{Li}} v_{\mathrm{Li}}+x_{\mathrm{Na}} v_{\mathrm{Na}}+x_{\mathrm{Cs}} v_{\mathrm{Cs}}} .
$$

The suffixes $\alpha$ and $\beta$ refer to two ions among $\mathrm{Li}^{+}$,

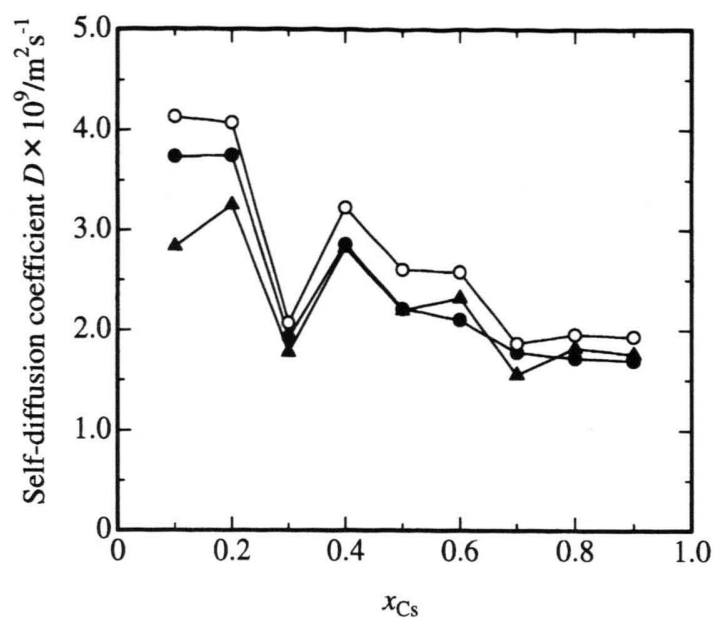

Fig. 3-1. Relationship between the self-diffusion coefficients of $\mathrm{Li}^{+}$: black circles, $\mathrm{Na}^{+}$: white circles, $\mathrm{Cs}^{+}$: black triangles and the mole fraction of $\mathrm{Cs}$ in molten $\mathrm{LiCl}-\mathrm{NaCl}$ eutectic melts at $900 \mathrm{~K}$.

$\mathrm{Na}^{+}$and $\mathrm{Cs}^{+}$, and $x$ is the mole fraction. The obtained relative differences in the corresponding mole fractions for the chlorides and fluorides were tabulated in Tables 3-1 and 3-2, respectively. The calculation of $\varepsilon_{\mathrm{Cs} \text {,solv. }}$ in the quasi-binary system $(\mathrm{Cs}, \mathrm{Li}-\mathrm{Na}) \mathrm{Cl}$ was in accordance with [1] in order to compare the results from the quasi-binary system $(\mathrm{Cs}, \mathrm{Li}-\mathrm{K}) \mathrm{Cl}$ and (Cs, Na-K)Cl. The observed Chemla crossing points in chloride melts were at $x_{\mathrm{Cs}}=0.2-0.3$ for Li-Cs, $x_{\mathrm{Cs}}=0.7-0.8$ for Na-Cs and $x_{\mathrm{Cs}}=0.5-0.6$ for quasi binary $(\mathrm{Cs}, \mathrm{Li}-\mathrm{Na})$ pairs. Li-Na pair had no Chemla crossing point in the range of $873-1023 \mathrm{~K}$ [18], which was consistent with our calculations, results and the Chemla crossing point of Li-Cs pair for chlorides was in good agreement with the experimental results of $(\mathrm{Li}, \mathrm{Cs}) \mathrm{Cl}$ binary system [19]. These results allow us to conclude that it is most effective to recover concentrated $\mathrm{Cs}$ in $\mathrm{LiCl}-\mathrm{NaCl}$ equimolar melts, because the enrichment degree of $\mathrm{Cs}$ in $\mathrm{LiCl}-\mathrm{NaCl}$ melts is higher than that in $\mathrm{LiCl}-\mathrm{KCl}$ eutectic [10] and $\mathrm{NaCl}-\mathrm{KCl}$ equimolar mixtures [11]. For the fluoride melts, $x_{\mathrm{Cs}}=0.2-0.3$ for $\mathrm{Li}-\mathrm{Cs}, x_{\mathrm{Cs}}=0.6-0.7$ for $\mathrm{Na}-\mathrm{Cs}$ and $x_{\mathrm{Cs}}=0.4-0.5$ for the quasi-binary system $(\mathrm{Cs}, \mathrm{Li}-\mathrm{Na}) \mathrm{F}$. These results enable us to conclude that it is possible to enrich Cs in fluoride melts, although the enrichment degree of Cs in fluorides is smaller than that in chlorides.

The self-diffusion coefficients of chloride and fluoride melts were calculated from the mean square displacements according to the Einstein expression [20] 


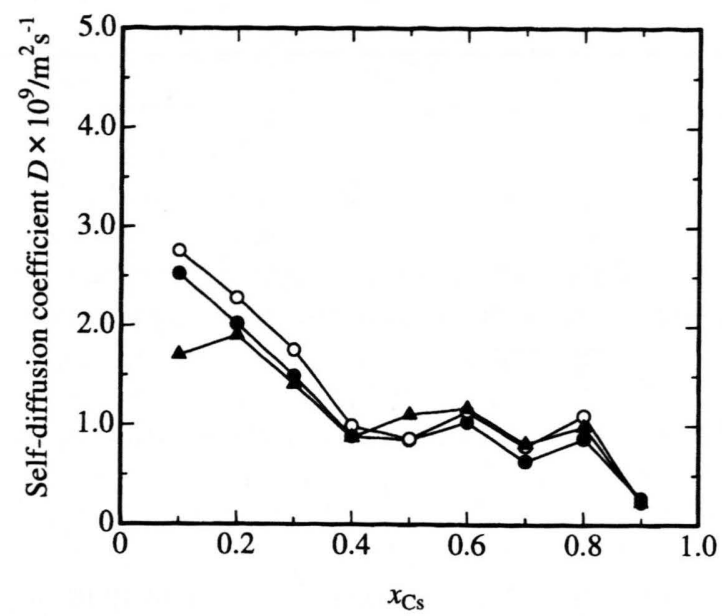

Fig. 3-2. Relationship between the self-diffusion coefficients of $\mathrm{Li}^{+}$: black circles, $\mathrm{Na}^{+}$: white circles, $\mathrm{Cs}^{+}$: black triangles and the mole fraction of $\mathrm{Cs}$ in molten $\mathrm{LiF}-\mathrm{NaF}$ eutectic melts at $925 \mathrm{~K}$.

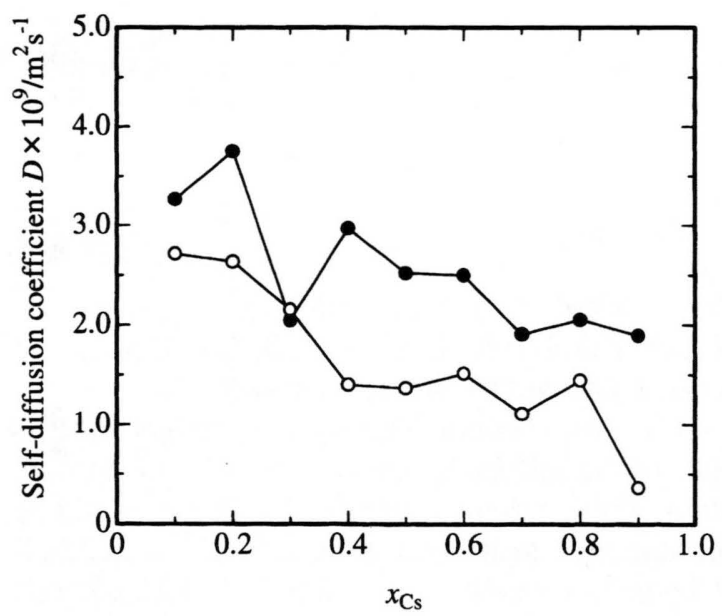

Fig. 3-3. Relationship between the self-diffusion coefficients of $\mathrm{Cl}^{-}$: black circles, and $\mathrm{F}^{-}$: white circles and the mole fraction of $\mathrm{Cs}$ in molten chloride and fluoride systems.

$$
D=\frac{1}{6} \frac{1}{d \tau}\left\langle\left\{r_{i}(t+\tau)-r_{i}(t)\right\}^{2}\right\rangle,
$$

as given in Figs. 3-1 and 3-2, respectively. The results obtained with the simulation predict that in this ternary mixture the order of the self-diffusion coefficient in chloride melts for each cation would be the following:

$$
\begin{aligned}
& D_{\mathrm{Cs}}<D_{\mathrm{Li}}<D_{\mathrm{Na}}\left(x_{\mathrm{Cs}}=0.1-0.3\right), \\
& D_{\mathrm{Cs}} \approx D_{\mathrm{Li}}<D_{\mathrm{Na}}\left(x_{\mathrm{Cs}}=0.4-0.5\right), \\
& D_{\mathrm{Li}}<D_{\mathrm{Cs}}<D_{\mathrm{Na}}\left(x_{\mathrm{Cs}}=0.6-0.9\right) .
\end{aligned}
$$

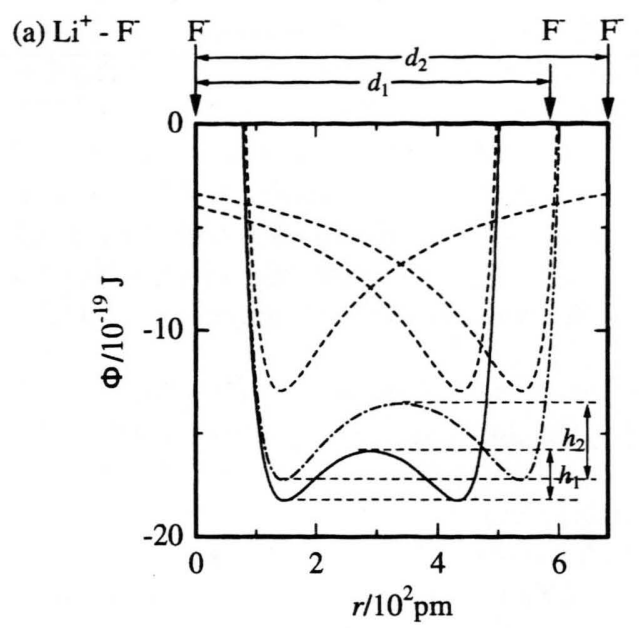

(b) $\mathrm{Cs}^{+}-\mathrm{F}$

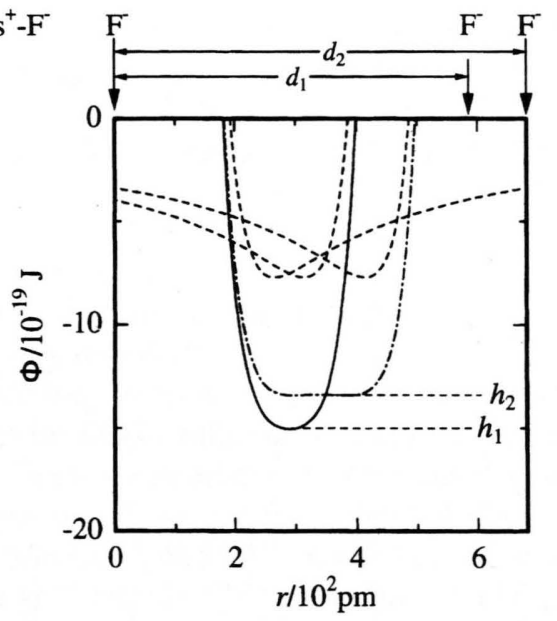

Fig. 4. Potential profiles for a cation collinearly located between anions separated by the distance $d$. Both axes are scaled for the case of $\mathrm{F}^{-}-\mathrm{Li}^{+}-\mathrm{F}^{-}$and $\mathrm{F}^{-}-\mathrm{Cs}^{+}-\mathrm{F}^{-}$; (a) $d_{1}=$ $580 \mathrm{pm}$ and (b) $d_{2}=680 \mathrm{pm}$. The left-hand $\mathrm{F}^{-}$is the reference anion.

For fluoride melts, the orders of the self-diffusion coefficients were

$$
\begin{aligned}
& D_{\mathrm{Cs}}<D_{\mathrm{Li}}<D_{\mathrm{Na}}\left(x_{\mathrm{Cs}}=0.1-0.2\right), \\
& D_{\mathrm{Cs}} \approx D_{\mathrm{Li}}<D_{\mathrm{Na}}\left(x_{\mathrm{Cs}}=0.3-0.4\right), \\
& D_{\mathrm{Li}}<D_{\mathrm{Na}}<D_{\mathrm{Cs}}\left(x_{\mathrm{Cs}}=0.7-0.9\right) .
\end{aligned}
$$

These are consistent with observations in our calculated self-exchange velocities, where the Chemla effect is observed for pairs of $\mathrm{Li}-\mathrm{Cs}$ and $\mathrm{Na}-\mathrm{Cs}$. The tendencies for $(\mathrm{Cs}, \mathrm{Li}-\mathrm{Na}) \mathrm{Cl}$ and $(\mathrm{Cs}, \mathrm{Li}-\mathrm{Na}) \mathrm{F}$ were 
relatively similar, i. e. the self-diffusion coefficients of each cation decreases with increasing Cs ratio. On the other hand, the self-diffusion coefficients of $\mathrm{Cl}^{-}$ and $\mathrm{F}^{-}$were presented in Fig.3-3. Each self-diffusion coefficient of $\mathrm{F}^{-}$was smaller than that of $\mathrm{Cl}^{-}$, which is consistent with the results of each pair correlation function because the increasing rate of peak heights for each cation in fluorides was larger than that in chlorides.

A step toward the understanding of the relation between the SEV and the internal mobility would be to apply a simplified potential model which considers the potential undergone by a cation located collinearly between two anions. These potentials for $\mathrm{Li}^{+}-\mathrm{F}^{-}$and $\mathrm{Cs}^{+}-\mathrm{F}^{-}$are obtained by superposing two pair potentials, as displayed in Figs. 4(a) and 4(b), respectively. As the distance, $d$, becomes longer from $d_{1}$ to $d_{2}$, the height of the barrier, $h$; becomes greater from $h_{1}$ to $h_{2}$, and the minimum position, which is the nearest one of the two from the reference anion, becomes nearer to this anion. The Li-F distance is shorter in the mixture than in pure $\mathrm{LiF}$ by as much as $20 \mathrm{pm}$, while the molar volume is much greater in the former than in the latter. As long as $h$ is higher than the kinetic energy, the cation cannot readily move away from the reference anion toward another. However, if the two anions approach each other by thermal motion, $h$ becomes low enough for the cation to surmount by kinetic energy. As the concentration of $\mathrm{CsF}$ increases, that is, the average value of $d$ increases from $d_{1}$ to $d_{2}$, it takes longer for the anions to touch one another. Thus, the SEV and internal mobility decrease with increasing concentration of CsF. Since $\mathrm{Li}^{+}$is much smaller than $\mathrm{Cs}^{+}$, the pair potential between cation and anion has a lower minimum at a greater distance for $\mathrm{Cs}^{+}$than for $\mathrm{Li}^{+}$. Therefore, the superposed potential has a much lower $h$ for $\mathrm{Cs}^{+}$than for $\mathrm{Li}^{+}$at a given $d$. Thus, the increase of $h$ with increasing $d$ is greater for $\mathrm{Li}^{+}$than for $\mathrm{Cs}^{+}$. This may be the reason why the internal mobility of Li decreases much more than that of Cs with increasing concentration of CsF,

[1] M. Matsumiya, H. Matsuura, R. Takagi and R. Fujita, J. Alloys Compd. 306, 87 (2000).

[2] M. Matsumiya, R. Takagi and R. Fujita, J. Nucl. Sci. Technol. 34, 310 (1997).

[3] M. Matsumiya and R. Takagi, Z. Naturforsch. 55a, 673 (2000).

[4] M. Matsumiya, M. Takano, R. Takagi and R. Fujita, J. Nucl. Sci. Technol. 35, 836 (1998). and this is the origin of the Chemla effect. As the difference in two cation size becomes larger, the difference in the slope of the isotherms of both mobilities with an increase in the concentration of the larger cation becomes greater. This is partly because the difference in the $h$ 's is greater, and partly because the increase of the molar volume, in going from the pure salt with the smaller cation to that with larger cation, is great. Comparing the potential profiles of $(\mathrm{Li}, \mathrm{Cs}) \mathrm{Cl}$ [10] with that of $(\mathrm{Li}, \mathrm{Cs}) \mathrm{F}$, the increase of the potential barrier of $(\mathrm{Li}, \mathrm{Cs}) \mathrm{F}$ with an increase from $d_{1}$ to $d_{2}$ is higher than that of $(\mathrm{Li}, \mathrm{Cs}) \mathrm{Cl}$. These profiles are consistent with the obtained pair correlation functions, the SEV and self-diffusion coefficients, and the increasing ratio of the calculated relative differences of $(\mathrm{Li}, \mathrm{Cs}) \mathrm{F}$ for each composition are higher than those of $(\mathrm{Li}, \mathrm{Cs}) \mathrm{Cl}$, although the temperature is a little different. For the future R\&D, we should estimate the energy required for the electromigration process by using data available for the fission yields at the equilibrium state as well as the data of $\varepsilon_{M}$ for each element. Furthermore, we should investigate the more complicated quaternary systems containing multivalent cations like Sr.

\section{Conclusion}

We inspected the self-exchange velocities and selfdiffusion coefficients in molten alkali chlorides and fluorides obtained by MD simulations. The orders of the self-diffusion coefficients were consistent with the results of the self-exchange velocities in this ternary system. These calculations revealed that it would be more effective to recover concentrated $\mathrm{Cs}$ in $\mathrm{LiCl}-$ $\mathrm{NaCl}$ equimolar melts than that in $\mathrm{LiCl}-\mathrm{KCl}$ eutectic and $\mathrm{NaCl}-\mathrm{KCl}$ equimolar mixtures and it is possible to enrich Cs in fluoride melts. Moreover, the maximal enrichment degree of Cs estimated from the calculated relative differences of the internal cation mobilities is $x_{\mathrm{Cs}} \approx 0.5-0.6$ in LiCl- $\mathrm{NaCl}$ equimolar mixtures and $x_{\mathrm{Cs}} \approx 0.4-0.5$ in LiF-NaF eutectic melts.

[5] M. Matsumiya, M. Takano, R. Takagi, and R. Fujita, Z. Naturforsch. 54a, 739 (1999).

[6] M. Matsumiya, R. Takagi, and R. Fujita, J. Nucl. Sci. Technol. 35, 137 (1998).

[7] Y. I. Chang et al., ANL-IFR-246 (1994).

[8] W. J. Hamer, M. S. Malmberg, and B. Rubin, J. Electrochem. Soc. 112, 750 (1965). 
[9] I. Okada, R. Takagi, and K. Kawamura, Z. Naturforsch. 34a, 498 (1979).

[10] M. Matsumiya and R. Takagi, Z. Naturforsch. 55a, to be published.

[11] M. Matsumiya, H. Matsuura, R. Takagi and R. Fujita, J. Electrochem. Soc. 147, 11 (2000).

[12] M. P. Tosi and F. G. Fumi, J. Phys. Chem. Solids 25, 45 (1964).

[13] J. E. Mayer, J. Chem. Phys. 1, 270 (1933).

[14] B. Larsen, T. Forland, and K. Singer, Mol. Phys. 26, 1521 (1973).
[15] P. P. Ewald, Ann. Phys. 64, 253 (1921).

[16] L. V. Woodcock, Chem. Phys. Lett. 10, 257 (1971).

[17] I. Okada, R. Takagi, and K. Kawamura, Z. Naturforsch. 35a, 493 (1980).

[18] Chao-Cheng Yang and Bor-Jih Lee, Z. Naturforsch. 48a, 1223 (1993).

[19] I. Okada, S. Okazaki, H. Horinouchi, and Y. Miyamoto, Materials Science Forum, Vol. 73-75, 175 (1991).

[20] N. Wax, Selected Papers on Noise and Stochastic Processes, Dover 1954. 